\title{
Environmental accountability for tobacco product waste
}

\author{
Thomas E Novotny
}

\section{Correspondence to}

Professor Thomas E Novotny, School of Public Health, San Diego State University, San Diego, CA 92182, USA; tnovotny@sdsu.edu

Published Online First 30 May 2019

\section{Linked}

- http://dx.doi.org/10.1136/ tobaccocontrol-2019-054956

Check for updates

(C) Author(s) (or their employer(s)) 2020. No commercial re-use. See rights and permissions. Published by BMJ.

To cite: Novotny TE.

Tob Control

2020:29:138-139.
In this issue of Tobacco Control, Hoek et al report on a survey of a representative sample of New Zealand smokers and non-smokers on their knowledge, attitudes and suggestions for potential interventions regarding the problem of tobacco product waste (TPW), otherwise known as cigarette butts. ${ }^{1}$ TPW is increasingly recognised by the public as the most common waste item picked up on beach and urban cleanups globally, ${ }^{2}$ and both smokers and non-smokers in Hoek's study recognised the potential environmental toxicity of TPW. Both also held smokers primarily responsible for preventing TPW, but after receiving additional information on the non-biodegradability of filters, more responsibility was assigned by both to the tobacco industry. However, the downstream perspective on TPW environmental accountability is still widely shared by most environmental groups, governments and the general public. Some environmental organisations are even supported by the tobacco industry as part of its 'greenwashing' efforts, ${ }^{3}$ and these well-meaning groups spend considerable time on clean-ups and in placing butt receptacles on beaches and street corners for TPW collection. Nonetheless, these efforts make little difference in mitigating the impact of trillions of cigarette butts dumped each year into the global environment. Simply put, clean-ups will not work to alleviate TPW despoilment. The dumping of toxic cigarette butts will remain normative as long as there are cigarettes to be smoked and smoking restrictions are unenforced. In addition, any 'biodegradable' alternative to the cellulose acetate filter attached to more than $90 \%$ of commercially sold cigarettes will still leach out toxic chemicals into the environment for months. ${ }^{4}$ Further, such a marketing element will potentially encourage smokers to dump their butts with less concern. The industry tried for years and failed to develop a marketable and biodegradable alternative to the cellulose acetate filter, despite its growing sensitivity to the environmental concerns raised by these waste products. ${ }^{5}$ Increasingly, discarded e-cigarettes and used Juul pods now beset the environment as trash, creating additional concerns for electronic, plastic and other potentially harmful waste products. ${ }^{6}$

Public health and environmental advocates need to recognise the significant overlap in each other's objectives in the war on butts. However, both groups do understand the value and efficacy of upstream interventions in their respective bailiwicks. For public health professionals, anything that reduces the normative behaviour of smoking, discourages the uptake of smoking and prevents secondary or tertiary exposures to tobacco toxins in the environment is part of the 'end game' for tobacco use. This endgame notion calls for 'new and politically risky' approaches along with stronger community engagement to achieve the end of the tobacco epidemic. ${ }^{7}$

For environmental professionals and advocates, extended producer responsibility (EPR), including contaminant source reduction and product changes, is a hallmark upstream approach to environmental protection. According to the Organisation for Economic Co-operation and Development, EPR is 'a policy approach under which producers are given a significant responsibility-financial and/ or physical-for the treatment or disposal of postconsumer products. ${ }^{8}$ This approach certainly seems to apply to TPW mitigation, as Hoek and others have asserted. ${ }^{19}$ Responsibility for TPW prevention extends across the entire life cycle of product use and disposal, but accountability has not yet been shifted upstream to the tobacco industry; it still remains with the epidemic's victims or as an externality for which communities and taxpayers pay. ${ }^{10}$

How might a coalition of environmental and public health groups enact policies to shift accountability for TPW upstream? First, the information gaps on TPW and filters identified by Hoek ${ }^{1}$ and others ${ }^{11}$ must be corrected. Cigarette filters are not biodegradable, nor do they protect against the harms of smoking. ${ }^{12}$ Second, filters are essentially an additive to the tobacco product and can thus be regulated through sales restrictions in many jurisdictions, ${ }^{13}$ as is now being done for flavoured additives in tobacco products. ${ }^{14}$ The sale of filtered cigarettes can be prohibited upstream in order to protect the environment while at the same time inhibiting the uptake of smoking by youth and encouraging quitting among current smokers. Third, more research is needed to understand the impact on smokers of a ban on the sales of filtered cigarettes, but this research would certainly follow the admonition to engage in 'new and politically risky' interventions to achieve the endgame against tobacco use.

The tobacco industry will likely use lawsuits, surrogate front groups, intense lobbying and extensive misinformation campaigns to resist any such EPR actions, as they have done with other public health interventions throughout recent history. ${ }^{15}$ They have used corporate social responsibility (CSR) to divert negative environmental public opinions, ${ }^{16}$ and they have funded beach clean-up programmes, ${ }^{17}$ lauded their own ecoconsciousness $^{18}$ and generally tried to deny any upstream responsibility for TPW. That can change with bold local, state or national environmental 
policies to shift accountability for TPW to the tobacco industry through EPR legislation. ${ }^{19}$ It can also change through the pursuit of legal remedies for TPW as a public nuisance ${ }^{20}$ and through increased public information about the impact of TPW, including that of e-cigarettes and Juul, on the environment and public health. In the case of TPW mitigation, public health and environmental advocates can engage with communities to undertake 'bold and politically risky' actions to bring accountability for the most commonly littered item on the planet back to the tobacco industry, where it belongs.

Contributors TEN originated this Commentary and is the sole author.

Funding The authors have not declared a specific grant for this research from any funding agency in the public, commercial or not-for-profit sectors.

Competing interests None declared.

Patient consent for publication Not required.

Provenance and peer review Commissioned; externally peer reviewed.

ORCID ID

Thomas E Novotny http://orcid.org/0000-0001-9235-0582

\section{REFERENCES}

1 Hoek J, Gendall P, Blank ML, et al. Butting out: an analysis of support for measures to address tobacco product waste. Tob Control.

2 Novotny TE, Slaughter E. Tobacco product waste: an environmental approach to reduce tobacco consumption. Curr Envir Health Rpt 2014:1:208-16.

3 Smith EA, McDaniel PA. Covering their butts: responses to the cigarette litter problem. Tob Control 2011;20:100-6.

4 Slaughter E, Gersberg RM, Watanabe K, et al. Toxicity of cigarette butts, and their chemical components, to marine and freshwater fish. Tob Control 2011;20(Supplement 1):i25-9.
5 Novotny T, Lum K, Smith E, et al. Cigarette butts and the case for an environmental policy on hazardous cigarette waste. IJERPH 2009;6:1691-705.

6 Hendlin YH. Alert: public health implications of electronic cigarette waste. Am J Public Health 2018;108:1489-90.

7 Malone RE. The race to a tobacco endgame. Tob Control 2016;25:607-8.

8 OECD. Extended producer responsibility. Available: http://www.oecd.org/env/toolsevaluation/extendedproducerresponsibility.htm

9 Curtis C, Collins S, Cunningham S, et al. Extended producer responsibility and product stewardship for tobacco product waste. Int J Waste Resources 2014;4.

10 Schneider JE, Peterson NA, Kiss N, et al. Tobacco litter costs and public policy: a framework and methodology for considering the use of fees to offset abatement costs. Tob Control 2011;20(Suppl 1):i36-41.

11 Rath JM, Rubenstein RA, Curry LE, et al. Cigarette Litter: Smokers' Attitudes and Behaviors. IJERPH 2012:9:2189-203.

12 Harris B. The intractable 'filter problem.'. Tob Control 2011;20(Suppl 1):9-15.

13 Freiberg M. (Don't) See More Butts: Preemption and Local Regulation of Cigarette Litter. Hamline Law Review: Vol. 37: Iss. 1, Article 6. Available: http://digitalcommons. hamline.edu/hlr/vol37/iss $1 / 6$

14 Public Health Law Center. U.S. sales restrictions on flavored tobacco products. September, 2018. Available: https://www.publichealthlawcenter.org/sites/default/files/ resources/US-Sales-Restrictions-Flavored-Tobacco-Products-2018.pdf

15 Saloojee Y, Dagli E. Tobacco industry tactics for resisting public policy on health. Bull World Health Organ 2000;78:902-10.

16 Hirschhorn N. Corporate social responsibility and the tobacco industry: hope or hype? Tob Control 2004;13:447-53.

17 Smith EA, Novotny TE. Whose butt is it? tobacco industry research about smokers and cigarette butt waste. Tob Control 2011;20(Suppl 1):i2-9.

18 Houghton F, Houghton S, O' Doherty D, et al. 'Greenwashing' tobacco products through ecological and social/equity labelling: A potential threat to tobacco control. Tob Prev Cessat 2018:4.

19 Curtis C, Novotny TE, Lee K, et al. Tobacco industry responsibility for butts: a model tobacco waste act. Tob Control 2017;26:113-7. (ISSN: 1468-3318).

20 Witkowski J. Holding cigarette manufacturers and smokers liable for toxic butts: potential litigation-related causes of action for environmental injuries/harm and waste cleanup. Tul Envt/ LJ 2014:28:1-36. 